\title{
One Health, One National Park: A Contribution to New Perspectives and Economics for Modern Times
}

\begin{abstract}
One Health is a concept that sees human, animal, and environmental health as parts of a single interdependent system. The Covid-19 pandemic, its implications reaching far beyond the direct effects of a coronavirus on people's health, underlines the importance of this increasingly influential perspective. In practice, One Health has its roots in early affiliations of human and animal health science. Over time, each sphere of inquiry evolved to address its own agenda. Recently, veterinary scientists have led the reintegration, extension, and promotion of One Health sciences to address modern-day problems in which health and people's general wellbeing are viewed as inseparable. A prerequisite is to set out a framework of concepts and principles enabling clear definition of problems, interrelationships needing to be understood, and the level of aggregation appropriate for quantitative analysis. This paper extends the framework by considering economic trade-offs that inevitably must be made in the human, animal, and environmental sub-systems, and the consequences when policy interventions are superimposed on them. The New Forest National Park in southern England is a case where this perspective is essential. Following the Stone Mountain definition of One Health, first a conventional approach linking human and animal health is taken. Lyme disease, Alabama rot, bovine tuberculosis and strangles are examples of diseases known to be of significant concern. The focus is finding scope for socially efficient risk reduction in response to mitigation resource use. Superimposed on the grazing livestock subsystems are support payments for commoner farmers. The financial incentives provided by what effectively are headage payments have caused animal inventories to grow so much that the wider environment may well be subject to adverse spillover effects that merit investigation.
\end{abstract}

Keywords: One Health, systems, risk, mitigation resources, Lyme disease, Alabama rot, strangles, bovine tuberculosis, New Forest National Park, England.

Dr Keith S. Howe, University of Exeter, Centre for Rural Policy Research (CRPR), Lazenby House, Prince of Wales Road, Exeter, Devon, EX4 4PJ, UK; Royal Veterinary College, University of London; k.s.howe@ exeter.ac.uk, ORCID: 0000-0003-2582-6813. 


\section{Introduction}

The Covid-19 pandemic of 2020 has uncertain long-term implications for society world-wide. Given the scale and distribution of consequent economic and social disruption, one outcome should be wider acceptance of need to interpret societal issues from a systems analysis perspective. Growing acceptance of the One Health concept, originating in the veterinary sciences and particularly veterinary epidemiology, pre-dates the pandemic. Some 70 per cent of all human infectious diseases originate in animal populations, i.e. are zoonoses, so identifying common interests in human and animal health as a foundation for scientific enquiry is sensible. But recognising the close links between human and animal health is not new, more a rediscovery. History shows many areas of commonality in human and animal health science. Over time, the fields diverged. Each followed its own agenda and, with different priorities, evolved its institutional structures for research, teaching and practical application. (Woods, Bresalier 2014; Woods, Bresalier, Cassidy, Dentinger 2018).

The evolution of the modern One Health concept is outlined in a series of papers published in the Veterinary Record, Journal of the British Veterinary Association (Gibbs 2014; Oura 2014; Dixon, Dar, Heymann 2014). Expansive accounts of One Health as it has evolved so far are found in Zinsstag et al. (2015), Rüegg et al. (2018), and Deem et al. (2019). An advance on earlier perspectives is the attention now devoted to environmental considerations alongside the human and animal dimensions of health. In part, this reflects ongoing exploration of the extent to which EcoHealth, another evolving concept, may overlap One Health potentially to a point of convergence (Harrison et al. 2019). It represents awareness that ecological factors such as wildlife health, effects of climate change, and how human stewardship of natural processes with conservation objectives, are all part of a complex system of interacting elements. Ecological and conservation aspects of One Health are surveyed by Cumming and Cumming (2015).

\section{National Parks and Health}

This paper takes the arguments further. It addresses the issue of how policy decisions affecting resource allocation in a national park relate to One Health outcomes. In other words, it includes economic considerations because of their implications for relationships between people, animals, and the environment they inhabit. The context is the New Forest National Park in southern England, its physical and institutional characteristics outlined in Howe $(2018)^{1}$. In the UK,

\footnotetext{
1 Also accessible at https://newforestassociation.org/wp-content/uploads/2019/01/Contesting-theCommons-compressed.pdf (accessed: June 2020).
} 
national parks exist as a place of human habitation and work as well as to promote well-being by giving people opportunities to appreciate nature, enjoy landscape, feel a sense of contributing to the conservation of natural and cultural systems on behalf of later generations, and as a location for sport, recreation and relaxation.

Work in the New Forest spans the ancient tradition of commoning, a system of mainly small-scale animal production integral to management of the semi-natural environment, as well as forestry and small-scale retail, services, and hospitality sectors that characterise the village settlements. A prime visitor destination, the National Park is also home to many self-employed professional people and retirees. In brief, the particular qualities marking the New Forest as worthy of special attention are that it is a location where people, animals, and the environment coexist in such close proximity that they variously complement and compete with each other's claim for 'health'. In that sense, the New Forest provides a real-world context for exploring One Health from the perspective of relationships needing to be understood as a basis for making policy decisions best placed to optimise net social benefits.

\section{New Forest Purposes}

The statutory purposes for the New Forest are enshrined in legislation (Environment Act 1995, Part III, which revised the 1949 National Parks and Access to the Countryside Act) applying to all thirteen national parks in England and Wales. These are to

1. Conserve and enhance the natural beauty, wildlife and cultural heritage

2. Promote opportunities for the understanding and enjoyment of the special qualities of national parks by the public

An important qualification is that when national parks carry out the above purposes, they also have the duty to seek to foster the economic and social wellbeing of local communities within them. Moreover, if it appears that there is a conflict between those purposes, the so-called Sandford Principle (after Lord Sandford, who chaired the National Parks Policy Review Committee for England and Wales, 1971-74) requires the National Park Authority to attach greater weight to the first. The latter caveat is especially important, not least because of conflicting pressures that lead to difficult trade-offs.

The word 'health' appears nowhere in the statutory purposes, but there is no question about the importance attached nowadays to the role of national parks and similar outdoor areas e.g. Public Health England (2017), HM Government (2018), Glover (2019), RSPB (2020), Buchan and Collins (2020). All such considerations are 
fully consistent with The Constitution of the World Health Organisation (WHO), 1948 , which states that

"The objective of WHO is the attainment by all peoples of the highest possible level of health. Health is a state of complete physical, mental, and social well-being and not merely the absence of disease or infirmity. The enjoyment of the highest attainable standard of health is one of the fundamental rights of every human being."

One qualification applies; in contemporary usage, health is normally regarded as a component of well-being, not the reverse as in the older WHO definition. As we have seen, One Health explicitly includes animals and the environment as part of a much wider interactive system. Zoonoses affect people's health directly, as do vagaries of the environment such as drought, but people's well-being depends on more than acquiring freedom from malevolent forces. For example, companionship of a pet, or enjoyment of a beautiful view, are other sources of benefit. For that reason, the more comprehensive term 'well-being' is used here in preference to 'health' unless the distinction is important, such as to avoid confusing understanding of the widely accepted term 'One Health'.

\section{One Health Revisited}

Of several variants, the Stone Mountain definition of One Health ${ }^{2}$ specifies that it is a comprehensive approach to health that focuses on

A. Improving health and well-being through the prevention of risks and the mitigation of effects of crises (e.g. emerging diseases) that originate at the interface between humans, animals, and their various environments.

B. Promoting multi(cross) sectoral collaborations and a 'whole of society' treatment of health hazards, as a systemic change of perspective in the management of risk.

At its simplest, the basic components of One Health are shown in Figure 1.

Two related elements stand out in particular - reference to the prevention of risks and the management of risks. Risks are defined here as the chances of events occurring that detract from people obtaining a state of WHO-defined health i.e. complete physical, mental, and social well-being. According to the specific context, such events may include any cause of human or animal morbidity or mortality; fear of illness or death; people's loss of salary or wage income over a short, medium, or long term, depending on how long employment is curtailed by ill health; people's private savings expended on health support; supernumerary

2 Stone Mountain Process on One Health - Governance and Global Network October 31-November 1, 2011 Emory University, Atlanta, GA, USA. 
public health expenditures paid by government from tax revenues; expenditures on veterinary fees and medicines.

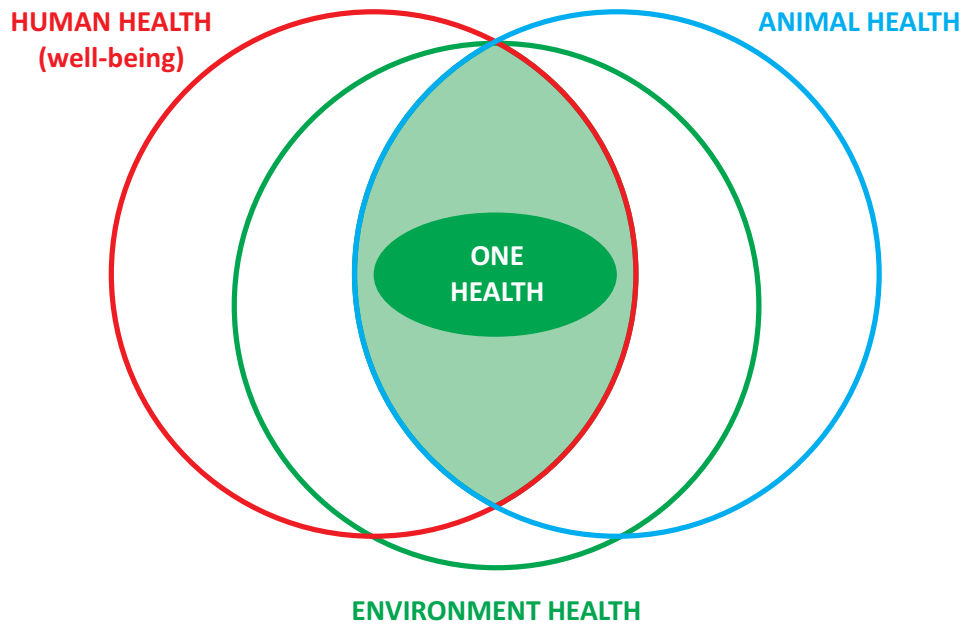

Figure 1. The basic components of One Health

Rysunek 1. Podstawowe komponenty koncepcji „Jedno Zdrowie” („One Health”)

Source: Own study.

Źródło: opracowanie własne.

The latter are familiar from conventional human and animal health economics. It is important to understand that all result from unwanted events occurring, and sources of wellbeing losses are both physical and psychological. Either they represent lost wellbeing directly experienced (e.g. as physical illness, fear, depression), or the opportunity cost of financial resources diverted from their intended consumption purposes in response to wellbeing loss (e.g. private savings intended for retirement spending in the long term, but having to be consumed now in compensation for earnings lost because of illness; public finance no longer available for government investment because requisitioned to assist people affected by disease, such as for both health and national economic support during the Covid-19 pandemic).

Given the present context, sources of people's lost wellbeing other than because of human or animal disease must be added to the list. Wellbeing losses of environmental origin may include people's negative feelings in response to spoilt visual landscapes, their concern about biodiversity loss or damage caused to rare species, fear of species extinction, losses of cultural origin e.g. artefacts (e.g. buildings, 
archaeological sites), and erosion of both physical features and valued longstanding social institutions (e.g. in the New Forest, the ancient practice of commoning).

The common element in all the above is what people value most of all, namely avoidance of lost wellbeing whatever the source. But Stone Mountain's 'prevention of risks' is a counsel of perfection, an ideal unattainable in practice because it involves the unavoidable need to make choices, and so trade-offs. Like value, trade-offs are core subject-matter of economics. From that perspective, One Health points to a framework, or model, for identifying relationships between the main variables to be considered. Sometimes these are quantifiable in monetary units and sometimes not, or not easily. In all circumstances, the first consideration is to establish a logical basis for decision-making, namely the definition of basic concepts and relationships that must precede quantification.

\section{Integrating Economics}

The general interpretation and implications of the Stone Mountain definition are explained in relation to Figure 2.

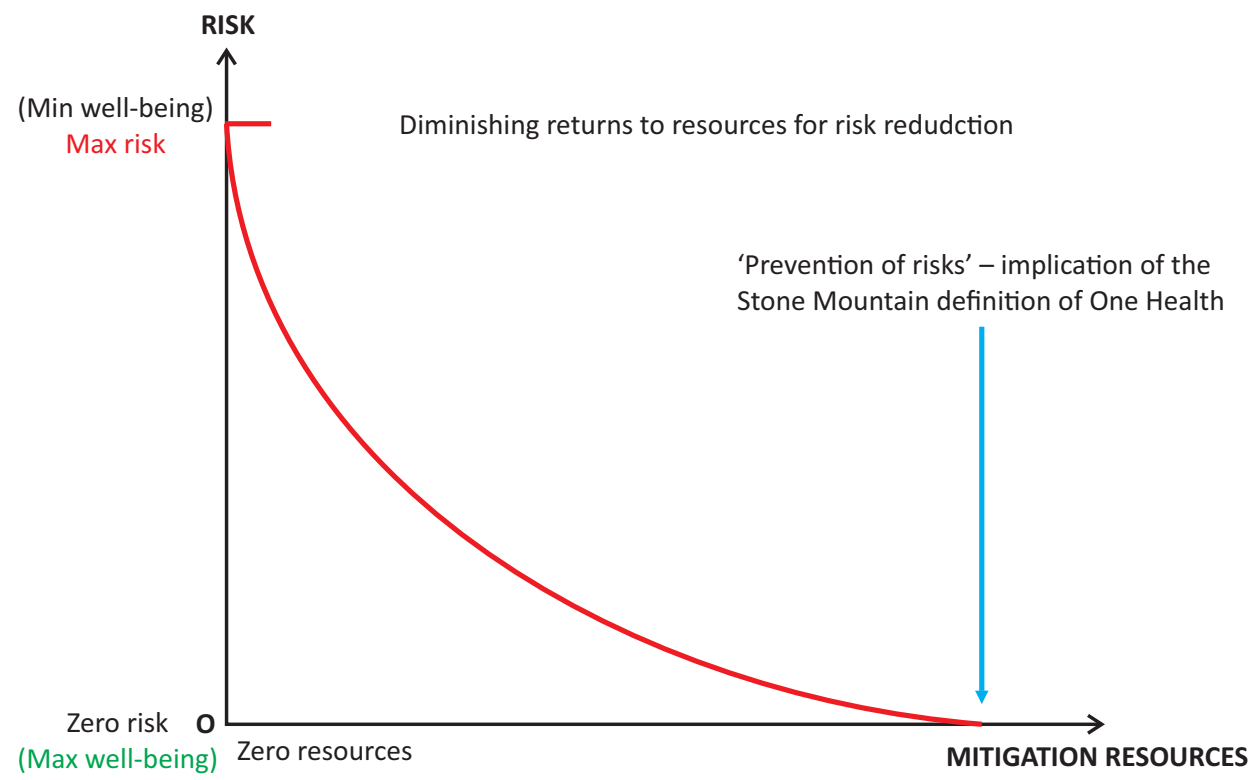

Figure 2. Generalised risk and resource trade-offs for One Health

Rysunek 2. Uogólniony rachunek ryzyka i zasobów w koncepcji „,Jedno Zdrowie” („One Health")

Source: Own study.

Źródło: opracowanie własne. 
The vertical axis shows risk levels increasing from zero (the origin) to the maximum level expected under current conditions (vertical intercept). In an ideal world of zero risk, well-being is therefore maximised; there is no loss because no bad events conspire to diminish it. More realistically, risk is at some level greater than zero, and its reduction needs the use of resources specifically targeted at that purpose. The curve describing the relationship between quantities of resources and risk levels is convex to the origin because diminishing returns to resource use are expected; as the quantities of mitigation resources are increased incrementally, the more difficult it becomes to achieve further marginal reductions in risk by adding yet more resources.

Figure $3 \mathrm{a}$ both modifies and builds on Figure 2. First, the risk-resources curve is shown not to intercept the horizontal axis, because risk typically cannot be eliminated. No matter how many resources are committed to mitigation, some risk will invariably remain. Currently, smallpox (human) and rinderpest (cattle) are the only diseases effectively at zero risk because of their world-wide elimination. Stone Mountain's 'prevention of risks' is therefore a worthy but still distant ambition. Second, risk is transformed into monetised benefit losses, expenditures (costs) of mitigation resources similarly so. For benefits particularly, the assumption is problematical for reasons evident from the above categorisation of physical and psychological losses but will suffice for immediate purposes. From a societal point of view, the interpretation is as follows.

Maximum risk is now the maximum monetary value of people's lost well-being without expenditure on mitigation resources. The emphasis on concern for losses accords with evidence that when making decisions people give more weight to what they may lose than gain (Kahneman, Tversky [1979]; Baumeister, Bratslavsky, Finkenauer, Vohs [2001]; McGraw, Larsen, Kahneman, Schkade [2010] ${ }^{3}$ ). With mitigation resource expenditures, losses decline incrementally until the curve flattens on reaching the 'unavoidable loss' boundary. Thereafter, use of additional mitigation resources is ineffective (zero marginal product in terms of any further recovered well-being) and so wasteful.

In Figure 3a, the relevant zone for decision-making is that labelled 'maximum feasible loss reduction'. Within that zone, the remaining issue is to identify the optimal combination of benefits in terms of reduction in lost well-being (implicitly, the associated risk level) and mitigation resource use, shown in Figure $3 \mathrm{~b}$.

3 Beyond the scope of this One Health paper, Yechiam, Hochman (2014) further investigate and appraise the evidence regarding focus on losses. 
BENEFIT LOSSES, $\mathbf{f}$

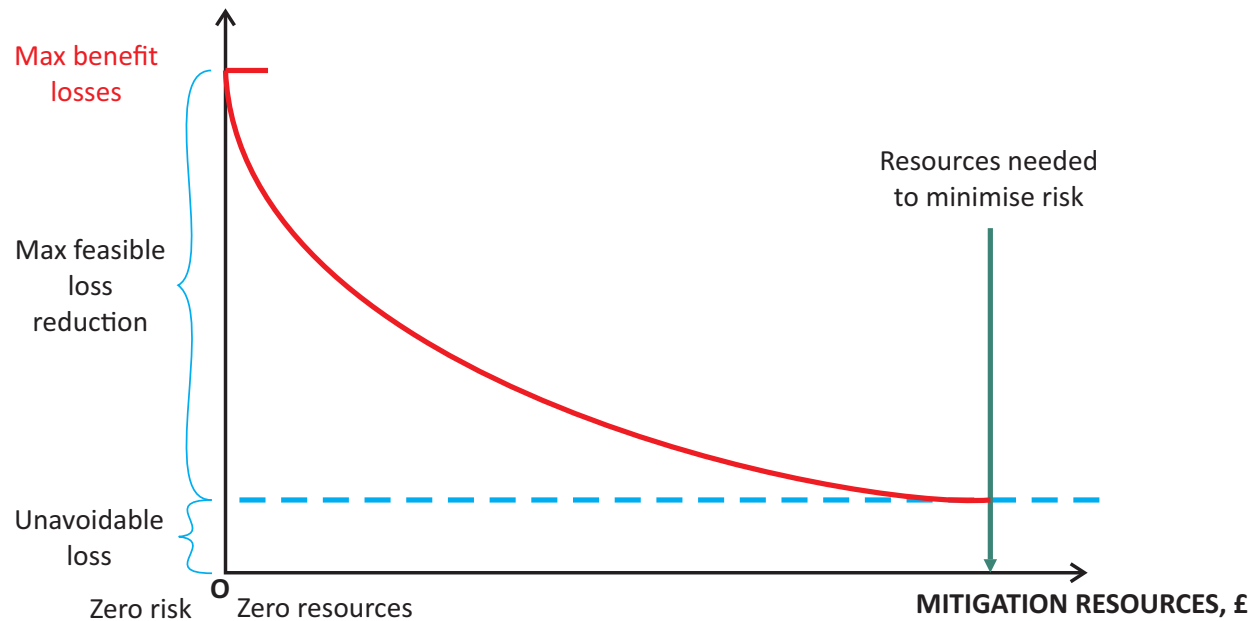

Figure 3a. The risk-resource curve as an economic relationship Rysunek 3a. Krzywa ryzyka i zasobów jako relacja ekonomiczna

Source: Own study.

Źródło: opracowanie własne.

\section{BENEFIT LOSSES, $€$}

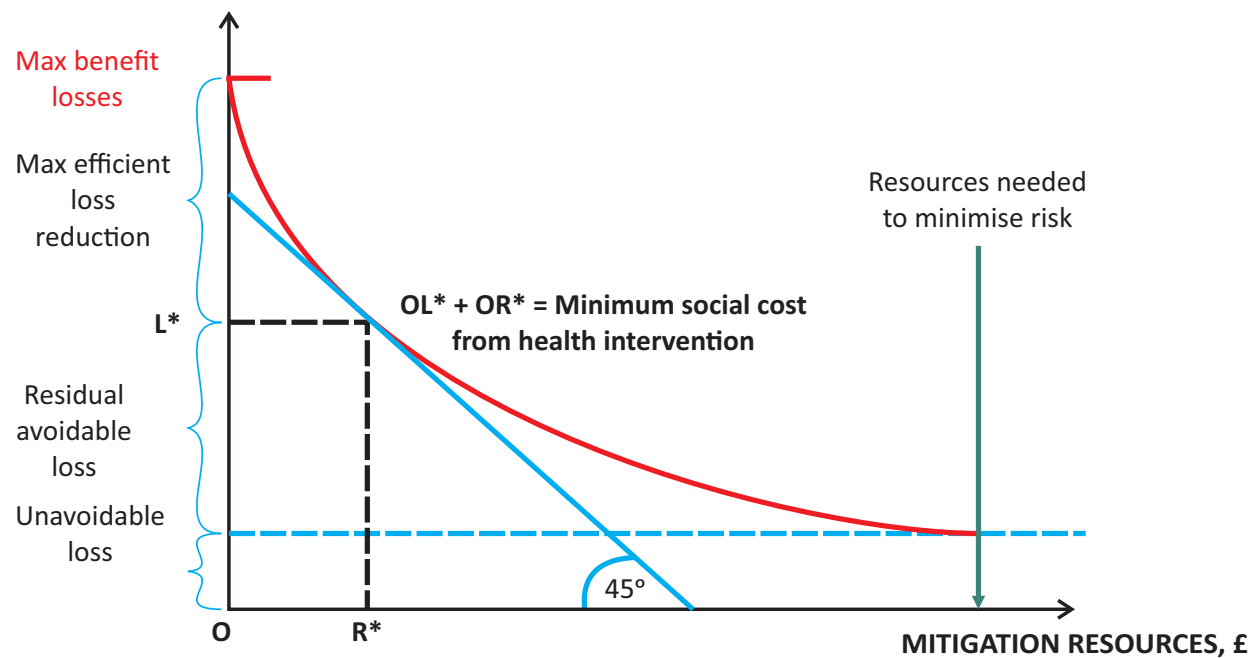

Figure 3b. Optimising well-being from risk mitigation resource use

Rysunek 3b. Optymalizacja dobrobytu względem wykorzystania zasobów łagodzenia ryzyka

Source: Own study.

Źródło: opracowanie własne. 
With benefit (well-being) losses and mitigation resources in money units, a $45^{\circ}$ line tangential to the curve defines the minimum social cost of resource-using interventions to reduce benefit losses, in total $\mathrm{OL}^{\star}+\mathrm{OR}^{\star}$. Over the range 0 to $\mathrm{R}^{*}$, the monetary value of increments of recovered benefits everywhere exceed the marginal mitigation resource costs of achieving them. To the right of $\mathrm{R}^{*}$, the reverse is so. Note that $\mathrm{OL}^{*}$ comprises two elements, a) residual avoidable loss, and b) unavoidable loss, of which only the former is open to reduction; unavoidable loss must be tolerated until, if possible, technical means are developed to shift the riskresource curve towards and, in the limit, to intersect the horizontal axis (Figure 2). At present, in terms of Figure 3b, (Maximum benefit losses - $\mathrm{OL}^{*}$ ) is the optimal social value of benefit losses avoided. According to the curve, it is technically possible to reduce lost benefits below $\mathrm{OL}^{*}$, but not worth it from the standpoint of economic efficiency.

\section{Applications and implications}

To investigate actual One Health issues by applying the economic logic, the following problems were selected. All are of significant concern in the New Forest: Lyme disease (Lyme borreliosis, LD), Alabama Rot (Cutaneous and renal glomerular vasculopathy, AR, bovine tuberculosis (Mycobacterium bovis, $\mathrm{bTB}$ ), ) and strangles (caused by Streptococcus equi, S). The choice was determined according to a) documented or anecdotal evidence of significant local health concerns, and b) the aim of representing a sufficient range of human and animal classes with close environmental interaction. Thus, in order, LD (zoonotic) affects people directly; AR is a disease of people's companion animals (dogs); bTB semi-feral cattle (currently a major national issue of concern to commoner farmers); $\mathrm{S}$ afflicts semi-feral ponies, horses and donkeys (a problem for residents, visiting equine owners, and active commoner farmers).

For interpretation, 'people' will therefore variously encompass all New Forest residents, the commoners, National Park visitors, and society at large. Also, the semi-natural New Forest environment is influenced by decisions made within a national planning framework and, for commoners, economic incentives provided by agricultural and environmental policy instruments. These are strictly exogenous to the human, animal and environmental sub-systems comprising One Health but, as will shall see, affects all three. Until Brexit in 2020, economic incentives were determined by the EU Common Agricultural Policy. Especially significant for commoners' animal production has been how the Basic Payment Scheme (BPS) was implemented. At the time of writing (June 2020) an Agriculture Bill before the UK parliament lays the foundations for future domestic 
arrangements. ${ }^{4}$ The BPS is being phased out in favour of an Environmental Land Management Scheme for public goods provision, while in future agricultural commodities production will be more exposed to international market forces. The exact methods and terms of future interventions are still under discussion. What is certain, not least for the New Forest, is that whatever the outcome, the implications will be profound.

\subsection{Lyme disease}

Lyme disease is a tickborne bacterial disease carried by animals and birds, especially prevalent in grassy and wooded areas of southern England. There is evidence of increasing annual incidence of confirmed cases, and suspicion that numbers are much higher. Without swift antibiotic treatment it can cause people health problems many years later, e.g. severe headaches, neck aches, heart problems, facial palsy and neuropathy, and arthritis with severe joint pain. Reports in both national and local media have raised awareness of risks, and the National Park Authority provides information on its 'staying safe' website. ${ }^{5}$

Applying the risk-resources model in the light of the information and present understanding of Lyme disease suggests characteristics outlined in Figure 4.

Given sufficient attention to preventive measures, such as wearing clothing to cover bare skin, avoiding vegetation that hosts ticks, using 'tick twisters' to remove ticks that successfully access skin, visiting the New Forest only in months when ticks are least active, and checking that companion dogs have not carried ticks home, few resources apart from information should be needed to minimise risks of contracting Lyme disease. That said, anecdotal evidence obtained by the author tends to support the view that cases are under-reported. In discussion with village residents, some reveal that they themselves, or a family member, or an acquaintance have had Lyme disease. This is a public health issue that merits closer investigation.

Organised walks also are popular in the New Forest. Walk leaders are obliged to address safety issues, including protection from ticks. 'Tick twisters' are sometimes provided. Although in total the resource expenditures needed to mitigate risks should be small, a special case may be in instances of educational visits for school children from low income families. Potentially unable to afford suitable protective clothing, they could be at elevated risk, hence the question mark in Figure 4. Health (well-being) is for everyone, and people of all backgrounds and ages should be able

4 See https://services.parliament.uk/bills/2019-21/agriculture.html (accessed: June 2020).

5 https://www.newforestnpa.gov.uk/visiting/visitor-information/staying-safe/ (accessed: June 2020). 
to benefit from National Park statutory purposes. Not only is well-being valuable for its own sake, understanding and enjoyment, SP2, should engender commitment to SP1, to conserve and enhance the natural beauty, wildlife and culture (in short, the environment) for future generations.

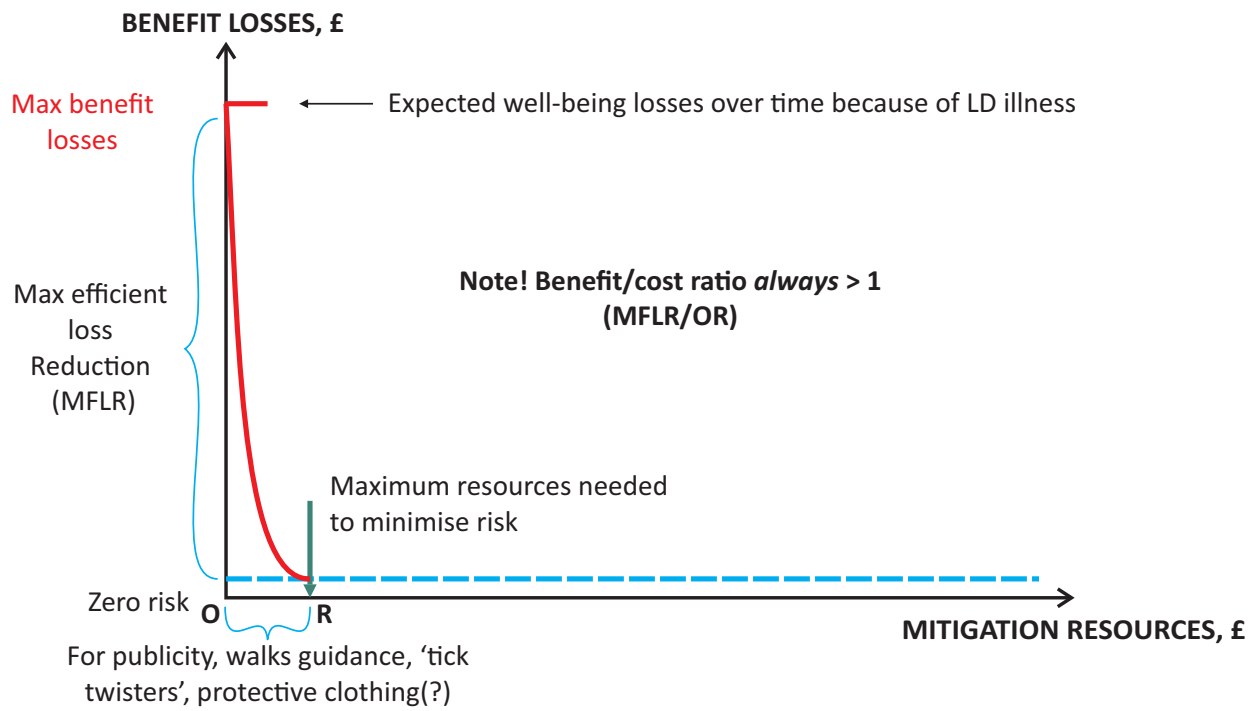

Figure 4. Hypothesised economic risk-resources model for Lyme disease Rysunek 4. Hipotetyczny model ekonomiczny zależności między ryzykiem a zasobami dla boreliozy

Source: Own study.

Źródło: opracowanie własne.

Regarding benefit losses (and implicitly risk levels), Lyme disease potentially may cause life-long debility, including days - or longer - lost from work. Estimating the monetary value of total benefit losses requires recourse to standard health economics methods (Drummond, Sculpher, Claxton, Stoddart, Torrance 2015) and Lyme disease incidence data. Economic evaluation must take time distributions for both benefit losses and resource expenditures explicitly into account so that, after discounting, they are comparable at present values.

Figure 4 indicates that benefit losses are expected to be low if simple, mainly inexpensive preventive measures are taken. How people choose to act in response to information is critical. Assuming the best outcome, benefit losses avoided should be obtainable for very low resource expenditures. If not, because people fail to take preventive measures, the economic losses are both private and social. They will 
include the opportunity cost of all health service resources used for treatment, including antibiotics such as doxycycline, amoxicillin, and cefuroxime axetil, diverted from other potential use.

For overall economic efficiency, the shape of the trade-off curve in Figure 4 indicates that the optimal outcome is where benefit losses, and so risk, are minimised. In conventional benefit/cost terms, the ratio of reduced benefit losses (losses avoided) to mitigation resource expenditures is greater than unity everywhere along the curve. For policy purposes, the conclusion is that whatever resources are necessary should be expended to enable people to remain free from Lyme disease - if they are sensible about their personal behaviour, a basis for empirical investigation.

Lyme disease suffices to illustrate the essential logic that should underpin analysis in any similar context. As the following discussion shows, that is so even where the shape of a losses/resources curve can only be a matter for speculation pending empirical work.

\subsection{Alabama Rot}

First identified in the USA during the 1980s, hence the name, since 2012 there have been a total of 204 confirmed cases of Alabama Rot across 43 counties in the UK, of which 19 were in 2016, 40 in 2017, 46 in 2018, and 29 reported (note, not confirmed) in 2019. Though still very rare, the disease is on the increase. The cause is unknown, it affects dogs regardless of age, sex, weight, or breed, and is thought to be associated with walking dogs in muddy areas. Particularly significant in the present context is that the New Forest abounds with muddy locations and watercourses and, when first noticed, most cases appeared to be in the New Forest area. Dog walking is widespread, both for family pets and by commercial dogwalkers. ${ }^{6}$ The initial symptoms are sores or ulcers on a dog's legs, chest and abdomen followed by signs of kidney damage. Because the kidneys seem to be affected quite severely, a catastrophic loss of renal function is highly likely. The likelihood of death in those cases is around 90 per cent.

In contrast to Lyme disease, the nature of mitigation resources for Alabama Rot currently is somewhat different. Information about avoidance of potentially high-risk environments, namely muddy areas, is similarly expected to be cheap to provide. However, for the foreseeable future the main part of mitigation efforts almost certainly will be research. An Alabama Rot Research Fund Charity was established in 2016 , its aim to raise $£ 240,000$ "to promote research into all aspects

\footnotetext{
6 See RJS Associates Ltd. (2018) for data on all recreational activities in the New Forest.
} 
of the disease known as Alabama Rot in dogs, on terms that the results of such research are published, with the aim of advancing education in the disease and guiding treatment and prevention strategies to relieve the suffering of dogs, who are in need of care and attention" (https://www.arrf.co.uk/). This indicates owners' and others' willingness-to-pay for dogs' health protection, to which should be added other sources of financial support, and imputed monetary values for unpaid services which some veterinary scientists are known to give.

In principle, financial support for the Charity from the New Forest Dog Owners Group may be taken as a measure of the value attributed to protecting the local dog population. In practice, Alabama Rot is more an instance of where the national, even international, context is most relevant for identifying and evaluating the risk-resource trade-offs. A first task is to specify the key variables. For instance, whether a dog is pedigree bred or a mongrel makes a difference to valuation. Fear of potentially losing a pet is a benefit loss to an owner who may be willing to pay substantially for its avoidance, should it be possible to do so. At present, there are many unknowns, much ignorance of objective risks. As a disease showing increasing incidence, longitudinal epidemiological studies are needed. The impact of climate change also should be considered. Given the extent of its muddy areas, the New Forest is a natural candidate for investigating whether more frequent or protracted dry periods have a positive effect of disease incidence. In the case of Alabama Rot, much remains to be learned about the characteristics of the trade-off curve.

\subsection{Bovine tuberculosis}

Currently not considered to be a significant problem in the New Forest, bovine tuberculosis (bTB) continues to be a major animal health problem in England and Wales. It disrupts both technical and farm economic dimensions of cattle production, is extremely stressful for cattle farmers, a source for political dispute between farmers and environmentalists, and a financial burden on the national budget. (Independent Scientific Group on Cattle TB 2007; King 2007; Godfray, Donnelly, Hewinson, Winter, Wood 2018; Animal \& Plant Health Agency, 2019).

The High Risk Area (HRA) of England and Wales for bTB lies in the relatively mild and wet western counties, which explains why most cattle and sheep production is found there. The Low Risk Area (LRA) to the east is typically drier, winters colder, and the land flatter, all conditions favourable to arable crop production. Geography places the New Forest at the southern end of the intermediate 'Edge Zone' (EZ). Sea borders its eastern and southern aspects, the Avon river valley its western, leaving 
only the northern side open to unimpeded land access from mainly rural areas, themselves part of the EZ.

Given its relatively protected location, why consider bTB in the New Forest? The reason is that economic policy incentives have had dramatic unintended consequences for the grazing animal population, mainly cattle but also the indigenous ponies and other equines (see next section). The unique Forest ecology, justifiably claimed to have long been fostered and protected by commoners' farming practices, may be inadvertently damaged by overstocking. Also, increased semiferal animal populations are potentially a larger reservoir for infectious disease, not only bTB. The problem arose for the following reason.

The EU Basic Payment Scheme (BPS) is an area payment system for individual farmers, which therefore posed a problem for graziers sharing access to common land. How the New Forest single area payment is converted into individual commoner payments is complex and beyond the scope of this paper. Briefly, payments to commoners are implemented as a sum received per livestock unit, essentially a type of headage payment. Crucially, from 2015 changes to the system incentivised farmers to register rights to graze more animals on the common, irrespective of whether they all did. Forest stocking rates is a highly sensitive issue and, if questioned, a reply such as "some of the cattle never see the Forest on their way to Salisbury market" is not unusual. For that reason, the interpretation of raw data from the Commoners Defence Association, the source for Figure 5, is problematical.

Figure 5 conflates a previously published chart with recently published data. Cattle numbers are seen to have shown considerable variation since the 1950s but, until recent years, with no discernible trend. The absolute numbers are of much less interest in the present context than the relative numbers. By any standards, stock numbers recorded in the marking register (i.e. animals for which owners have paid an annual fee for the right to graze them on the commons) have hugely increased over recent years, reflecting the size of net profit earned under BPS support. If it is assumed that the number of cattle registered to graze the common is identical to the highest ever recorded in the mid-1970s (just over 3000 head), in 2019 the exact provenance and destination of some 5300 animals - common grazed or direct to market? - is uncertain. Some of the increased numbers will be Forest bred; but others necessarily will be purchased from outside, possibly originating in the HRZ. So, the efficiency of veterinary measures to detect and eradicate animals infected with bTB is critical to maintaining the Forest's status as essentially bTB free. ${ }^{7}$

In terms of Figure 3a, the current situation for bTB in the New Forest is that the risk and mitigation resource co-ordinates are close to the origin. Given

\footnotetext{
7 See https://tbhub.co.uk/tb-policy/england/ for details (accessed: June 2020).
} 
the conspicuous impact of policy intervention for animal inventories, a third dimension must be added. Viewing Figure $3 \mathrm{a}$ as a horizontal plane, Figure 6 shows it supplemented by a vertical axis for animal numbers.

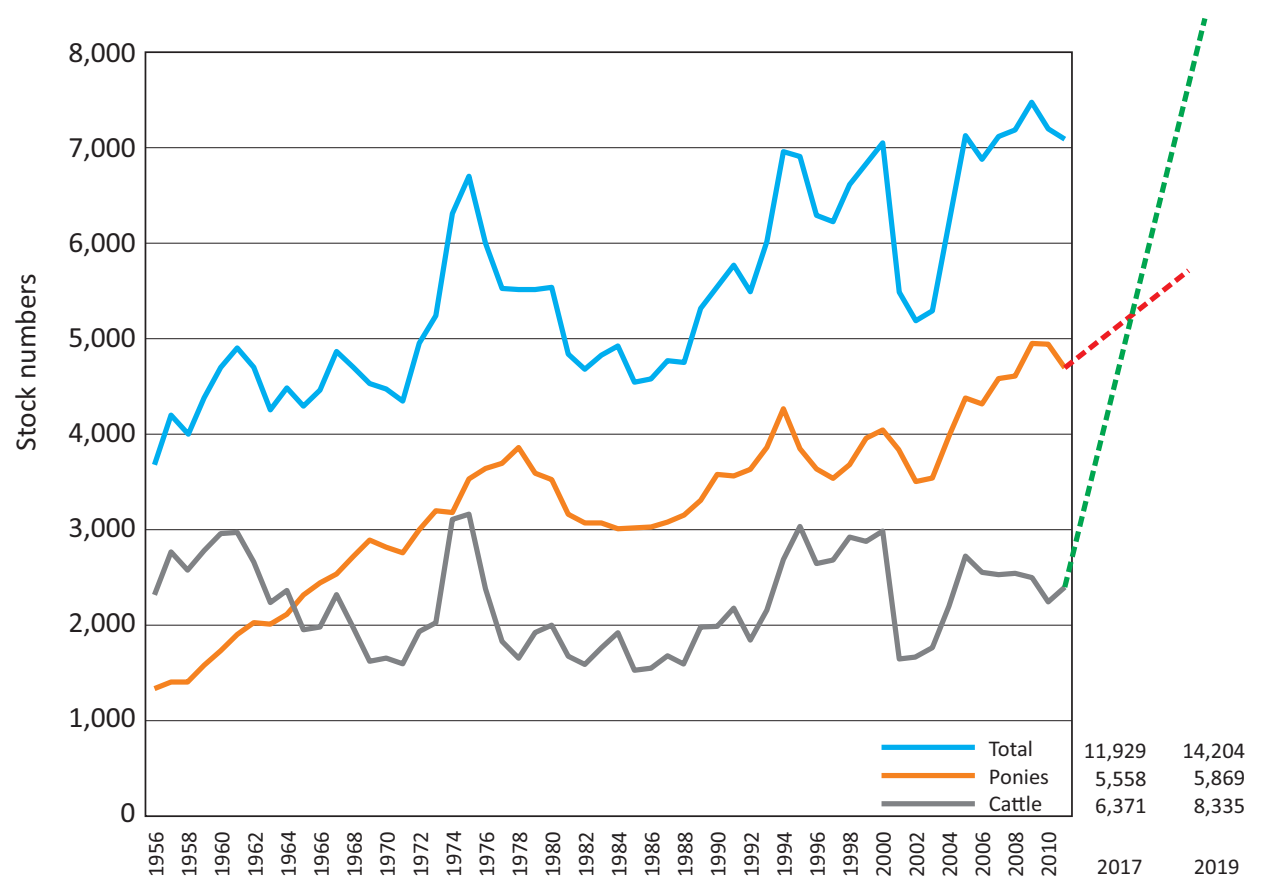

Figure 5. Changes in marking register stock numbers in the New Forest 1956-2019 Rysunek 5. Zmiany w oznaczaniu sztuk rejestrowych w Parku Narodowym New Forest w latach 1956-2019

Source: Cox (2013, Figure 7) \& Commoners Defence Associaton (2019).

Źródło: Cox (2013, Rysunek 7) i Commoners Defence Association (2019).

New Forest cattle numbers are explained by a supply function of the general form

$$
N_{A}=f(P, S, C, F, W),
$$

where: $\mathrm{N}_{\mathrm{A}}=$ Total number of cattle registered marked (per annum); $\mathrm{P}=$ Gross output - acquisition price (per animal sold); $\mathrm{S}=$ BPS subsidy, per livestock unit; $\mathrm{C}=$ Variable costs, per animal; $\mathrm{F}=$ Marking fee paid, per animal.

Figure 6 shows a single arbitrary outcome for cattle numbers generated by the supply function, $\mathrm{N}_{\mathrm{A}}$. Benefit losses from $\mathrm{bTB}$ comprise the monetary value of infected animals culled, taxpayer losses because of compensation payments, and 
imputed monetary values for farmers' psychological stress (from which veterinarians too are not immune) and any associated medical treatments. Mitigation resources include provision for tuberculin skin testing, blood sampling, post-mortem inspection and tissue culture, and associated veterinary inputs. Trade-off curves 1,2, and 3 in Figure 6 are hypothetical, drawn from the set of all feasible options, and serving to illustrate variations in underlying technical relationships between risk, benefit losses and mitigation methods. Similar curves will be associated with other levels of $\mathrm{N}_{\mathrm{A}}$. In simple terms, for any given size of cattle population the task is to ascertain which approach to risk reduction for bTB, i.e. trade-off curve, is technically the best and for which the minimum social cost (mitigation expenditures + remaining benefit losses) is derived.

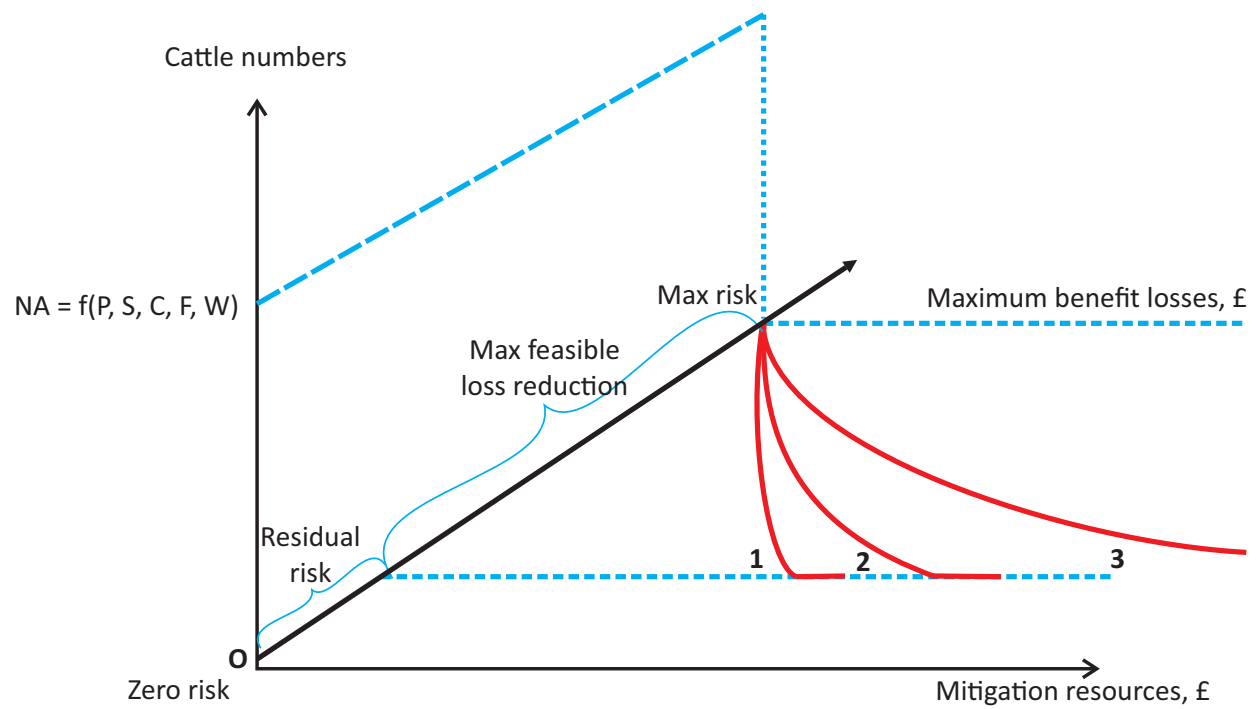

Figure 6. Risk-resource trade-offs adjusted for cattle numbers

Rysunek 6. Rachunek ryzyka i zasobów w odniesieniu do liczby sztuk bydła

Source: Own study.

Źródło: opracowanie własne.

\section{Strangles}

Strangles, a highly contagious respiratory infection caused by bacterium Streptococcus equi, is one of the most common equine diseases. In favourable conditions, bacteria can survive outside a host for weeks or even months. Its symptoms include fever, appetite loss, nasal discharge, and swollen lymph nodes. In severe cases an abscess forms in the back of the throat, sometimes leading to internal swelling and 
a collapse of the airways, effectively 'strangling' the sufferer and giving the disease its name. "The disease is extremely unpleasant for the horse and expensive for the owner in terms of veterinary care and recovery time. Strangles is not usually fatal but a small number of horses have complications including spread of infection to multiple organs and this can prove life threatening. Veterinary care is essential in combating this disease and to prevent its spread." (Scotland's Rural College ${ }^{8}$ )

Strangles is contracted by direct contact between horses or indirect contact with infected material, such as feeding bowls, water troughs or shared tack and equipment. For the semi-feral New Forest ponies, two main sources of risk are suspected. First, direct contact between animals who assemble and drink at the many watercourses and ponds. Also relevant is that in 2014 a particularly bad outbreak of strangles ( 6 ponies died) caused 11 out of 34 drifts (i.e. pony roundups) to be cancelled. The drifts enable pony auction sales to be combined with welfare management. If they had gone ahead, disease could have been spread both by close grouping animals subsequently returned to the Forest and by distant relocation of those sold.

Second, through petting and hand feeding, humans can also transfer strangles from infected animals (including sub-clinically) to otherwise healthy horses or ponies. It is speculated - there is no hard evidence - that people who stroke or feed the free-roaming ponies, which they ought not to do, may inadvertently spread the disease. On the most recent estimate, over 15 million visitor days were made to the New Forest in 2017 (RJS Ltd. 2018). According to the National Park Authority, this amounts to more visitor days per square kilometre of protected conservation land than in any other English national park. Justifiably, the ponies are described as iconic to the New Forest, many visitors coming to enjoy seeing them in their natural environment. Valuing the activity in monetary units is difficult, if not impossible. Less problematical is valuing losses from cancelled pony sales. Market prices for ponies can be volatile and low, yet sales contribute to commoners' incomes. Also, hunters and other sport horses are kept and ridden in the New Forest, each with a value reflecting its quality, and all susceptible to strangles.

Overall, estimating the monetary value of benefit losses from strangles may be less problematical than for mitigation resource costs. As for Lyme disease, information provision should be cheap, leaving horse and pony keepers to make their subjective risk assessments of chances that their horses and ponies may be infected. Uncertain consequences of current weather conditions or longer-term climate trends for bacteria prevalence are another consideration. Like cattle,

8 https://www.sruc.ac.uk/info/120473/premium_assured_strangles_scheme/1363/strangles_disease (accessed: June 2020). 
economic incentives from national policy decisions have played a role in increasing equine numbers. Unlike cattle, the economic drivers are more complex, more than a straightforward supply response by commoner farmers. The long-term upward trend in pony numbers revealed in Figure 5 is also driven by recreational horse and pony keeping by New Forest residents, some of them incomers able to enjoy the fruits of increased income and wealth (Howe 2018). In short, for equines Figure 6 is itself a partial account of the relationships to be considered, needing to be supplemented by income and wealth data.

\section{Conclusions}

Omitted from discussion here is explanation for why the New Forest is so crowded with people. In simple economic terms, the main reason is that people get what it provides too cheaply. With National Park status, it is an exceptionally attractive place for living, working, and recreation. Doubtless the delusion of cheapness the costs of negative externalities are seldom paid - helps to explain why all such areas feature so prominently in current national policies to promote health and wellbeing (Glover 2019). In practice, any disturbance occasioned by problems in animal health, or environmental damage caused by misplaced policies, or human overcrowding especially, has negative whole-system effects. From that perspective, the New Forest serves well as a model for appraising the usefulness of the One Health concept as a basis for analysing real-world problems. This paper shows that the powerful simplicity of economic principles is indispensable to One Health's task of disentangling and understanding the origins, scope of, and threats to people's wellbeing at the interface of human, animal, and environmental health. One Health need not fall into the trap of trying to explain everything about everything, which review of its burgeoning literature suggests it could.

Thinking in terms of complete systems does not come naturally to most people. The substance of most of this paper was presented at a public lecture of the Royal Veterinary College and the London School of Hygiene and Tropical Medicine, London University, at the annual general meeting of Friends of the New Forest in the presence of National Park officials, commoners and veterinarians, and in a university seminar. Unsurprisingly, academics steeped in One Health thinking are comfortable with the approach; but others find they are being asked to think 'in the round' for perhaps the first time. For that reason, taking a partial analytical approach by considering each of Lyme disease, Alabama rot, bTB and strangles separately against a background of general principles may help contribute to its acceptance. The approach adopted also has the advantage of contrasting health and wellbeing issues for which data are relatively accessible to those where it is not. 
Even if monetary valuation of some variables is extremely difficult if not impossible, for example measuring the value people attach to the fear of ill-health, or animal suffering, or a damaged precious natural environment, the essential logic that they must be included in decision-making should always be observed.

Omission of valuations because of such measurement constraints also hinders identification of optimal economic outcomes. In principle, optimal allocation of mitigation resources across the individual problem contexts requires solution for equi-marginal returns. As outlined elsewhere (Howe 2018) the New Forest is an interesting example of a place where different decision-making institutions work to a broadly common purpose. With sufficient co-operation, jointly pursuing the equi-marginal principle - however intuitively - should lead to better outcomes. In any event, if a partial approach enables monetary valuation of what are considered the most important types of benefit loss and mitigation resources, then conduct the analysis aware of omissions. If, say, in benefit/cost ratio terms an outcome indicates mitigation is worthwhile (e.g. $\mathrm{B} / \mathrm{C}>1$ in the hypothesised Lyme disease example), then make informed judgements about unmeasured variables (e.g. fear of contracting disease) to modify interpretation of the 'raw' result before deciding what to do.

Concern for how people achieve at least 'good health', then maintain and preferably improve it as a contribution to their general wellbeing, has been lifted to new levels by the Covid-19 pandemic. The unprecedented costs of dealing with its social and economic consequences - unemployment, bankruptcies, stress, over-stretched health service personnel and other resources, increased national indebtedness have thrust ideas about how to relieve pressures on society by means conducive to people's better health other than relying on expensive ways to repair the system when things go wrong. Physical exercise, recreation, relaxation, and access to fresh air are all routes to avoiding obesity, diabetes, cancers, heart disease, and so on, at low economic cost. In parallel, repairing environmental damage to our fragile planet, stopping biodiversity loss, reducing atmospheric and other pollution to prevent catastrophic climate change, are all responses to human society's failure to acknowledge the that actions in one sphere of life have consequences for others. Again, Covid-19 is a reminder that human, animal, and environment health are interwoven and, with them, so much else. Moreover, what happens everywhere on a local scale adds to global benefits, and the New Forest case study is one example of that. 


\section{Bibliography}

Animal \& Plant Health Agency (2019). Year End Descriptive Epidemiology Report: Bovine TB Epidemic in the England Edge Area. Delivery Area: Southern, Name of County: Hampshire. Year-end report for: 2018. TR398 (Rev. 08/19) Department for Environment, Food and Rural Affairs

Baumeister R.F., Bratslavsky E., Finkenauer C., Vohs K.D. (2001). Bad is stronger than good. Review of General Psychology, 5, 323-370.

Buchan K., Collins F. (2020). The Tree Surgery. Broadleaf, the Woodland Trust, No 101, Summer, 19-23.

Cumming D.H.M., Cumming G.S. (2015). One Health: an Ecological and Conservation Perspective. In Zinsstag et al. (op. cit.) Chapter 4, 38-52.

Deem S.L., Lane-deGraaf K.E., Rayhel E.A. (2019). Introduction to One Health: An Interdisciplinary Approach to Planetary Health. Wiley-Blackwell.

Dixon M.A., Dar O.A., Heymann D.L. (2014). Emerging infectious diseases: opportunities at the human-animal-environment interface. Veterinary Record, 174 (22), 546-551.

Drummond M.F., Sculpher M.J., Claxton K., Stoddart G.L., Torrance G.W. (2015). Methods for the Economic Evaluation of Health Care Programmes. Fourth edition. Oxford: Oxford University Press.

Environment Act (1995), http://www.legislation.gov.uk/ukpga/1995/25/contents (accessed: June 2020).

Gibbs E.P.J. (2014). The evolution of One Health: a decade of progress and challenges for the future. Veterinary Record, 174 (4), 85-91.

Glover J. (2019). Landscapes Review: Final report, Chapter 3. https://www.gov.uk/government/publications/designated-landscapes-national-parks-and-aonb (accessed: June 2020).

Godfray C., Donnelly C., Hewinson G., Winter M., Wood J. (2018). Bovine TB Strategy Review. Report to Rt Hon Michael Gove MP, Secretary of State, Defra. October.

Harrison S., Kivuti-Bitok L., Macmillan A., Priest P. (2019). EcoHealth and One Health: A theory-focused review in response to calls for convergence. Environment International, 132, 105058.

HM Government (2018). A Green Future: Our 25 Year Plan to Improve the Environment. https://assets.publishing.service.gov.uk/government/uploads/system/uploads/attachment_data/file/693158/25-year-environment-plan.pdf (accessed: June 2020).

Howe K.S. (2018). Contesting the Commons: Economics and Politics in the New Forest National Park of Southern England. Wieś i Rolnictwo, 179 (2), 85-112.

Independent Scientific Group on Cattle TB (2007). Bovine TB: The Scientific Evidence. Final Report.

Kahneman D., Tversky A. (1979). Prospect theory: An analysis of decision under risk. Econometrica, 47, 263-291.

King Sir D. (2007). Bovine Tuberculosis in Cattle and Badgers. A Report by the Chief Scientific Adviser to the Secretary of State, Department of the Environment, Food, and Rural Affairs. 
McGraw A.P., Larsen J.T., Kahneman D., Schkade D. (2010). Comparing gains and losses. Psychological Science, 21, 1438-1445.

National Parks and Access to the Countryside Act 1949. http://www.legislation.gov.uk/ ukpga/1949/97/pdfs/ukpga_19490097_en.pdf (accessed: June 2020).

Oura C. (2014). A One Health approach to the control of zoonotic vector-borne pathogens. Veterinary Record, 174 (16), 398-402

Public Health England and National Parks England (2017). An Accord between National Parks and Public Health England to support joint action on improving health and well-being through our national parks. September, 6 pages.

RJS Associates Ltd. (2018). New Forest Recreation and Leisure Visits. Report commissioned by the New Forest National Park Authority on behalf of the Recreation Strategy Steering Group. October.

RSPB (Royal Society for the Protection of Birds) (2020). Recovering Together: A report of public opinion on the role and importance of nature during and in our recovery from the Coronavirus crisis in England. June. https://www.rspb.org.uk/globalassets/downloads/recovering-together-report/ (accessed: June 2020).

Rüegg S.R., Häsler B., Zinsstag J. (2018). Integrated Approaches to Health: A Handbook for the Evaluation of One Health. Wageningen Academic Publishers.

Stringer A. (2014). Improving animal health for poverty alleviation and sustainable livelihoods. Veterinary Record, 175 (3), 526-529.

Woods A.M., Bresalier M. (2014). One health, many histories. Veterinary Record, 174 (26), 650-665.

Woods A., Bresalier M., Cassidy A., Dentinger R.M. (2018). Animals and the Shaping of Modern Medicine: One Health and its Histories. Medicine and Biomedical Sciences in Modern History. Palgrave Macmillan.

Yechiam E., Hochman G. (2013). Losses as modulators of attention: Review and analysis of the unique effects of losses over gains. Psychological Bulletin, 139, 497-518.

Zinsstag J., Schelling E., Waltner-Toews D., Whittaker M., Tanner M. (2015). One Health: The Theory and Practice of Integrated Health Approaches. CABI International.

\section{„Jedno Zdrowie”, jeden park narodowy: przyczynek do nowych perspektyw i gospodarki na nowe czasy}

Streszczenie: „Jedno Zdrowie” (One Health) to koncepcja, która postrzega zdrowie ludzi, zwierząt i środowiska przyrodniczego jako elementy jednego, współzależnego systemu. Pandemia Covid-19, której konsekwencje wykraczają daleko poza bezpośredni wpływ koronawirusa na zdrowie ludzi, uprzytamnia znaczenie tego coraz bardziej wpływowego ujęcia. W praktyce, „Jedno Zdrowie” ma swoje korzenie w dawnym powiązaniu nauk o zdrowiu ludzi i zdrowiu zwierząt. Z biegiem czasu każda sfera badań ewoluowała, wypracowując własne podejścia, metodologię i pytania badawcze. Ostatnio naukowcy z dziedziny 
weterynarii doprowadzili do reintegracji, rozszerzenia i promocji nauk o „Jednym Zdrowiu” w celu rozwiązania współczesnych problemów, w których zdrowie i ogólny dobrobyt nie byłyby postrzegane rozłącznie. Warunkiem wstępnym jest określenie ram pojęciowych i zasad umożliwiających jasne zdefiniowanie problemów, wzajemnych powiązań, a także poziomu agregacji odpowiedniego dla prowadzenia analizy ilościowej. Niniejszy artykuł poszerza te ramy poprzez uwzględnienie kompromisów gospodarczych, które w sposób nieunikniony muszą zostać osiągnięte w podsystemach ludzkim, zwierzęcym i przyrodniczym, oraz konsekwencji, jakie wiążą się z nałożeniem na nie interwencji politycznych. Park Narodowy New Forest w południowej Anglii to przypadek, w którym przyjęcie takiej perspektywy jest niezbędne. Zgodnie z definicją „Jednego Zdrowia” stosowaną przez Stone Mountain, w artykule przyjęto w pierwszej kolejności tradycyjne podejście łączące zdrowie ludzi i zwierząt. Borelioza, martwica z Alabamy, gruźlica bydła i zołzy to przykłady chorób stanowiących istotny problem. Główny nacisk należy położyć na znalezienie możliwości społecznie efektywnej redukcji ryzyka w odpowiedzi na zużycie „łagodzących” zasobów. Do podsystemów wypasowego chowu zwierząt gospodarskich przydzielane są płatności wspierające rolników użytkujących grunty wspólnot. Zachęty finansowe, będące faktycznie płatnościami od pogłowia, spowodowały tak duży wzrost inwentarza zwierząt, że szeroko pojęte środowisko przyrodnicze może w konsekwencji podlegać niekorzystnym efektom ubocznym zasługującym na osobne badanie.

Słowa kluczowe: „Jedno Zdrowie” (One Health), systemy, ryzyko, zasoby „łagodzące”, borelioza, martwica z Alabamy, zołzy, gruźlica bydła, Park Narodowy New Forest, Anglia. 